\title{
A novel class of $\mathrm{H}_{3}$ antagonists derived from the natural product guided synthesis of unnatural analogs of the marine bromopyrrole alkaloid dispyrin
}

\author{
J. Phillip Kennedy ${ }^{a, d}$, P. Jeffrey Conn ${ }^{b, c, d}$, and Craig W. Lindsley ${ }^{a, b, c, d, *}$ \\ aDepartment of Chemistry, Vanderbilt University, Nashville, TN 37232, USA

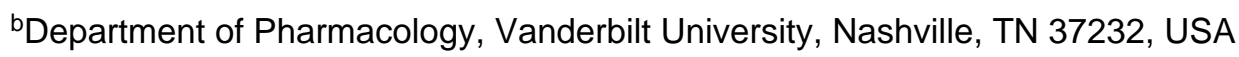 \\ 'Vanderbilt Program in Drug Discovery, Vanderbilt Institute of Chemical Biology, Vanderbilt \\ University, Nashville, TN 37232, USA \\ dVanderbilt Institute of Chemical Biology, Vanderbilt University Medical Center, Nashville, TN \\ 37232, USA
}

\begin{abstract}
This Letter describes the natural product guided synthesis of unnatural analogs of the marine bromopyrrole alkaloid dispyrin, and the resulting $\mathrm{SAR}$ of $\mathrm{H}_{3}$ antagonism. Multiple rounds of iterative parallel synthesis improved human $\mathrm{H}_{3} \mathrm{IC}_{50} \sim 33$-fold, and afforded a new class of $\mathrm{H}_{3}$ antagonists based on the novel bromotyramine core of dispyrin.
\end{abstract}

\section{Keywords}

H3 antagonist; Dispyrin; Marine natural product; Alkaloid

The neurotransmitter histamine exerts its action through four distinct Class A GPCRs $\left(\mathrm{H}_{1}-\right.$ $\left.\mathrm{H}_{4}\right) .{ }^{1-7}$ The histamine $\mathrm{H}_{3}$ receptor, a Gi/o-coupled receptor in the CNS, is a pre-synaptic auto- and heteroreceptor that not only controls the release of histamine, but also other neurotransmitters (acetylcholine, noradrenaline, dopamine, GABA and serotonin). ${ }^{1-7}$ Preclinically, $\mathrm{H}_{3}$ antagonists/inverse agonists have demonstrated efficacy in a number of CNS pathologies including schizophrenia, epilepsy, depression, pain, decreasing food intake, drug abuse and addiction, sleep disorders/narcolepsy and cognitive enhancement. ${ }^{1-7}$ Early reference $\mathrm{H}_{3}$ antagonists contained imidazole moieties, such as thioperimide $\mathbf{1}$ and Perceptin (GT-2331) 2 (Fig. 1). Effort from multiple companies then focused on nonimidazole $\mathrm{H}_{3}$ antagonists and include compounds such as UCL 1972 3, ABT-239 4, JNJ's 5, Novo Nordisk's 6, Eli Lilly's 7 and GSK189254 8 to exemplify a few (Fig. 1). This intense effort from the pharmaceutical industry led to the evolution of a refined $\mathrm{H}_{3}$ antagonist pharmacophore model 9. ${ }^{1-8}$

*Corresponding author. Tel.: +1 615322 8700; fax: +1 615343 6532. craig.lindsley @ vanderbilt.edu (C.W. Lindsley). 
We recently completed the first total synthesis of dispyrin $10,{ }^{9}$ a bromopyrrole alkaloid with a novel bromotyramine core, isolated by Crews in $2007^{10}$ from the marine sponge Agelas dispar (Fig. 2). Upon recognition that dispyrin 10 possessed the basic features of the refined $\mathrm{H}_{3}$ pharmacophore model 9, we evaluated our synthetic dispyrin against the human $\mathrm{H}_{3}$ receptor. Gratifyingly, dispyrin was found to have modest activity as an $\mathrm{H}_{3}$ antagonist $\left(\mathrm{IC}_{50}\right.$ $\left.=2.35 \mu \mathrm{M}, K_{\mathrm{i}}=1.04 \mu \mathrm{M}\right) .{ }^{9}$ Based on these data, we initiated a natural product guided synthesis effort, employing iterative parallel synthesis ${ }^{11}$ for molecular editing, aimed at improving $\mathrm{H}_{3}$ inhibition and binding; moreover, we wanted to validate the marine natural product dispyrin $\mathbf{1 0}$ as a viable lead molecule due to the novel scaffold providing intellectual property in extremely crowded chemical space.

The first generation 25 -member library was based on a $5 \times 5$ two-dimensional design wherein the core was held constant and the amide $\mathrm{R}^{1}$ and aminoalkyl moieties $\mathrm{R}^{2}$ varied (Scheme 1). The library synthesis began with a simple DIC amide coupling employing commercially available 3-bromo-4-methoxyphenylethylamine $\mathbf{1 1}$ with one of five heterocyclic carboxylic acids $\mathrm{R}^{1}$. These five scaffolds were then treated with $\mathrm{BBr}_{3}$ to remove the methyl ether liberating the free phenols 13. Each of the five phenols $\mathbf{1 3}$ was then alkylated with one of five aminoalkyl chlorides to install $\mathrm{R}^{2}$ under microwave-assisted conditions to afford unnatural dispyrin analogs 14 (Table 1).

This first generation library was highly informative. In general, all $\mathrm{R}^{1} \mathrm{~S}$ and $\mathrm{R}^{2} \mathrm{~s}$ afforded modestly potent $\left(K_{\mathrm{i}} \mathrm{s}\right.$ and $\mathrm{IC}_{50} \mathrm{~s}$ in the low micromolar range) $\mathrm{H}_{3}$ antagonists. Potent $\mathrm{H}_{3}$ antagonists $\left(K_{\mathrm{i}} \mathrm{s}<200 \mathrm{nM}, \mathrm{IC}_{50} \mathrm{~s}<430 \mathrm{nM}\right)$ resulted for all of the heterocyclic amides $\mathrm{R}^{1}$ in combination with the ethyl pyrrolidinyl $\mathrm{R}^{2}(\mathbf{1 4 c}, \mathbf{1 4 h}, \mathbf{1 4 m}, \mathbf{1 4 r}$ and $14 \mathrm{w})$. In contrast, the ethyl morpholino congeners $(\mathbf{1 4 d}, \mathbf{1 4} \mathbf{i}, \mathbf{1 4 n}, \mathbf{1 4}$ and $\mathbf{1 4 x})$ were uniformly weak $\left(K_{\mathrm{i}} \mathrm{s}>12\right.$ $\left.\mu \mathrm{M}, \mathrm{IC}_{50} \mathrm{~s}>29 \mu \mathrm{M}\right)$. The most potent $\mathrm{H}_{3}$ antagonist from the first generation library was $14 \mathbf{r}\left(\mathrm{R}^{1}=4\right.$-bromo-thiophene, $\mathrm{R}^{2}=$ ethyl pyrrolidine) with a $K_{\mathrm{i}}$ of $80 \mathrm{nM}$ and an $\mathrm{IC}_{50}$ of 180 $\mathrm{nM}$-a 13-fold improvement over the parent natural product dispyrin $10\left(\mathrm{IC}_{50}=2.35 \mu \mathrm{M}, K_{\mathrm{i}}\right.$ $=1.04 \mu \mathrm{M}$ ). Based on these data, the next library maintained $\mathrm{R}^{1}=4$-bromo-thiophene and surveyed functionalized pyrrolidines at $\mathrm{R}^{2}$ (Scheme 2).

Following Scheme 1, a large quantity of $\mathbf{1 5}$ was prepared. Then, the phenol was alkylated with 2-bromo-1,1-dimethoxy ethane to provide 16, which was then converted to the corresponding aldehyde 17 by treatment with tosylic acid. Finally, reductive amination employing a functionalized pyrrolidine and $\mathrm{MP}-\mathrm{B}(\mathrm{OAc})_{3} \mathrm{H}$ provided analogs $\mathbf{1 8}$. As shown in Table 2, analogs 18 were weaker $\mathrm{H}_{3}$ antagonists than $\mathbf{1 4}$, and there was no evidence of enantioselective inhibition (18a vs $\mathbf{1 8 b}$ ). In agreement with the $\mathrm{H}_{3}$ pharmacophore model, incorporation of $\beta$-fluorine atoms such as in $\mathbf{1 8 c}$ and $\mathbf{1 8 d}$, which lowers the $\mathrm{p} K_{\mathrm{a}}$ on the pyrrolidine nitrogen from 11 to 9 , afforded diminished $\mathrm{H}_{3}$ inhibition. ${ }^{13}$

We then prepared two singleton compounds following the synthetic route depicted in Scheme 1 with the appropriate substitutions, wherein the bromine in $\mathbf{1 4} \mathbf{r}$ was replaced with a chlorine 19 and a truncated version 20 (Fig. 3). A twofold diminution in potency was noted for $\mathbf{1 9}$, relative to $\mathbf{1 4 r}$, and the truncated benzyl version lost over 13 -fold compared to $\mathbf{1 4 r}$; however, this highlighted that the heavy bromine atom was not required for $\mathrm{H}_{3}$ inhibition. 
The final library iteration was directed at surveying a wider range of alternative amides (heterocycles and functionalized aromatic moieties) while holding the preferred ethyl pyrrolidine ether and bromotyramine core constant. The synthesis began with $\mathbf{1 1}$ and conversion to the phthalimide congener 21. Standard $\mathrm{BBr}_{3}$ deprotection provided 22 which was alkylated with chloroethyl pyrrolidine to deliver 23. Hydrolysis of the phthalimide with hydrazine, followed by amide coupling with a diverse collection of aryl and heteroaryl carboxylic acids generated library $\mathbf{2 4}$ (Scheme 3 ).

This third generation library was uniformly active, providing $\mathrm{H}_{3}$ antagonists in the submicromolar range. Six-member heterocycles, such as pyridine $\mathbf{2 4 a}$, were active, as were aryl amides with halogens $(\mathrm{Cl}$ and $\mathrm{Br})$ or trifluoromethyl groups in the 3-position $(\mathbf{2 4 f}-\mathbf{h})$. Fivemember heterocycles $(\mathbf{2 4 b}-\mathbf{e})$ proved optimal, with a 5-oxazole $\mathbf{2 4 b}\left(K_{\mathrm{i}}=32 \mathrm{nM}, \mathrm{IC}_{50}=83\right.$ $\mathrm{nM})$ and 2-thiazole $24 \mathrm{~d}\left(K_{\mathrm{i}}=32 \mathrm{nM}, \mathrm{IC}_{50}=72 \mathrm{nM}\right)$ affording the most potent $\mathrm{H}_{3}$ antagonists of the unnatural dispyrin analogs. For example, 24d improved the $\mathrm{H}_{3} K_{\mathrm{i}}$ and $\mathrm{IC}_{50} \sim 33$-fold over the natural product dispyrin, and required only three iterations of molecular editing and 40 analogs. Moreover, as dispyrin represented a novel chemotype, we were able to obtain composition of matter patents for the dispyrin analogs as $\mathrm{H}_{3}$ antagonists within an incredibly crowded intellectual property landscape. ${ }^{14}$ This effort highlights the value of employing natural products as leads for therapeutically relevant targets (Table 3).

In summary, a natural products guided synthesis effort in molecular editing, employing iterative parallel synthesis, quickly optimized the weak $\mathrm{H}_{3}$ antagonism of the marine natural product dispyrin 10 over 30-fold to afford unnatural analog 24d with low nanomolar potency and binding. By employing a novel natural product scaffold for lead optimization, we were able to establish an intellectual property position in an incredibly crowded intellectual property landscape. Although the role of natural products drug discovery efforts within the pharmaceutical industry is being significantly reduced, despite overwhelming success, the biological activity of dispyrin and its analogs argue further that natural products are viable drug leads and offer patenting advantages.

\section{Acknowledgments}

The authors thank the Vanderbilt Department of Pharmacology and the Vanderbilt Institute of Chemical Biology for support of this research. J.P.K. acknowledges a VICB predoctoral training fellowship.

\section{References and notes}

1. Celanire S, Wijtmans M, Talaga P, Leurs R, de Esch JP. Drug Discovery Today. 2005; 10:1613. [PubMed: 16376822]

2. Esbenshade TA, Brownman KE, Bitner RS, Strakhova M, Cowart MD, Brioni JD. Br J Pharmacol. 2008; 154:1166. [PubMed: 18469850]

3. Berlin M, Boyce CM. Exp Opin Ther Patents. 2007; 17:675.

4. Stocking EM, Letavic MA. Curr Top Med Chem. 2008; 8:988. [PubMed: 18673168]

5. Jesudason CD, Beavers LS, Cramer JW, Dill J, Finley DR, Lindsley CW, Stevens FC, Gadski RA, Oldham SW, Pickard RT, Siedem CS, Sindelar DK, Singh A, Watson BM, Hipskind PA. Bioorg Med Chem Lett. 2006; 16:3415. [PubMed: 16677814]

6. Wijtmans M, Leurs R, de Esch I. Exp Opin Invest Drugs. 2007; 16:967.

7. Hudkins RL, Raddatz R. Ann Reports Med Chem. 2007; 42:49. 
8. Santora VJ, Covel JA, Hayashi R, Hofilena BJ, Ibarra JB, Pulley MD, Weinhouse MI, Sengupta D, Duffield JJ, Semple G, Webb RR, Sage C, Ren A, Pereira G, Knudsen J, Edwards JEL, Suarez M, Frazer J, Thomsen W, Hauser E, Whelan K, Grottick AJ. Bioorg Med Chem Lett. 2008; 18:1490. [PubMed: 18194865]

9. Kennedy JP, Brogan JT, Lindsley CW. J Nat Prod. 2008; 71:1783. [PubMed: 18800848]

10. Pina IC, White KN, Cabera G, Rivero E, Crews P. J Nat Prod. 2007; 70:613. [PubMed: 17335245]

11. Kennedy JP, Williams L, Bridges TM, Daniels RN, Weaver D, Lindsley CW. J Comb Chem. 2008; 10:345. [PubMed: 18220367]

12. Leister WH, Strauss KA, Wisnoski DD, Zhao Z, Lindsley CW. J Comb Chem. 2003; 5:322. [PubMed: 12739949]

13. Fadeyi O, Lindsley CW. Org Lett. 2009; 11:943. [PubMed: 19159275]

14. Provisional patent $(61 / 059,975)$ filed. Jun 9. 2008 p. 3208 


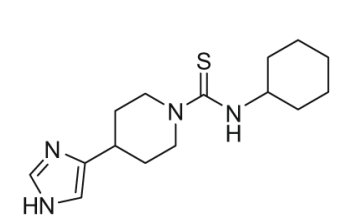

1, Thioperimide

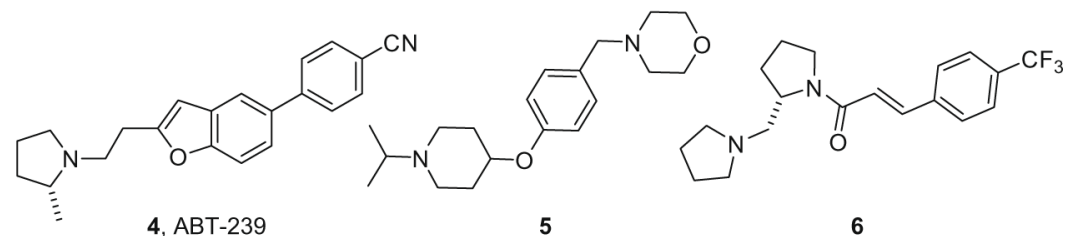

4, АBT-239
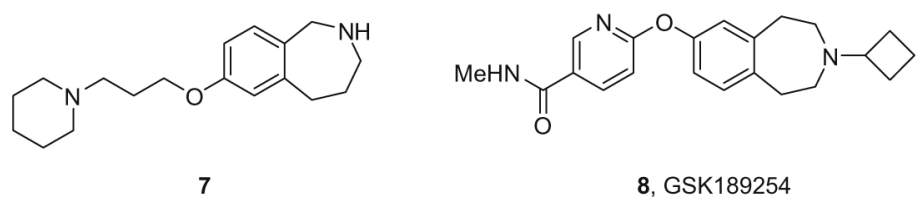

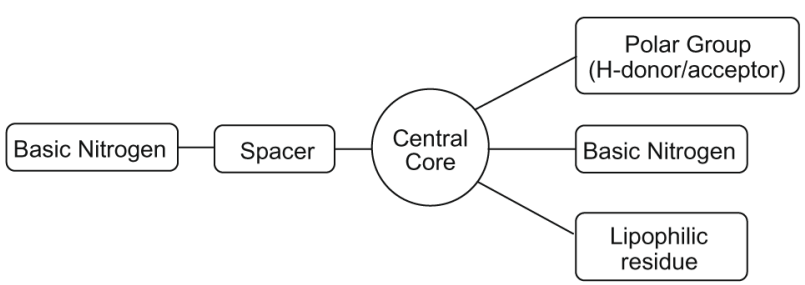

9, Refined $\mathrm{H}_{3}$ Pharmacophore Model

8, GSK189254$$
\text { H-donor/acceptor) }
$$

Figure 1.

Imidiazole and non-imidazole $\mathrm{H}_{3}$ antagonists 1-8 leading to a refined $\mathrm{H}_{3}$ pharmacophore model 9. 


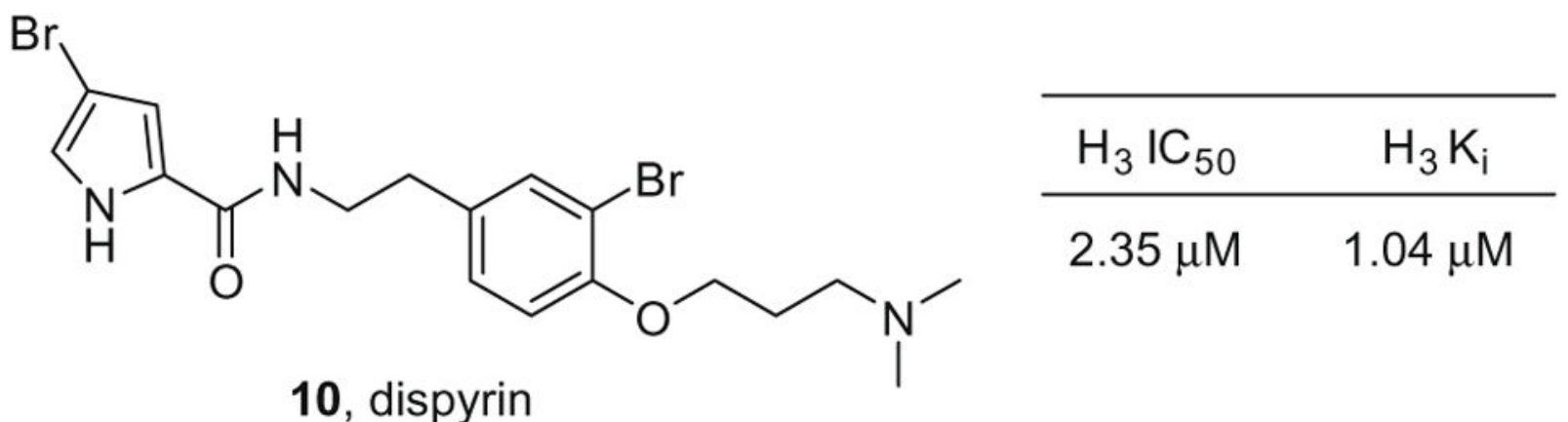

Figure 2.

Dispyrin 10, a novel bromopyrrole alkaloid from Agelas dispar with a bromotyramine core unprecedented in marine natural products. 

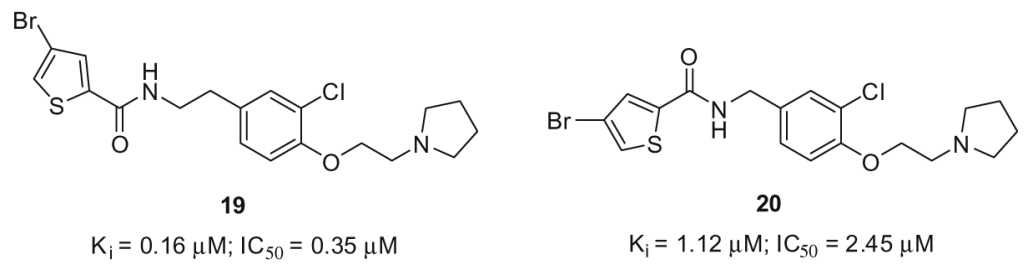

Figure 3.

Chlorinated version and chlorinated truncated version of $\mathbf{1 4 r}$. 
<smiles>[R]C(=O)NCCc1ccc(OC)c(Br)c1</smiles>

11<smiles>[R]C(=O)NCCc1ccc(O)c(Br)c1</smiles>

13
12

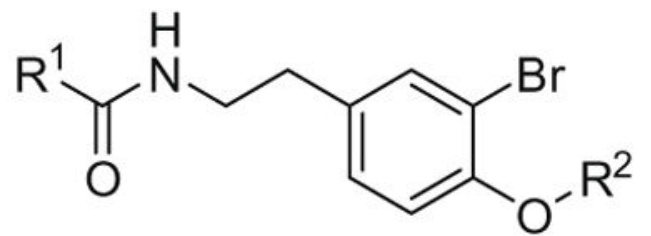

14

Scheme 1.

First generation library synthesis. Reagents and conditions: (a) $\mathrm{R}^{1} \mathrm{COOH}, \mathrm{DIC}, \mathrm{HOBt}$, DIEA, DCM, rt, 12 h (69-99\%); (b) $\mathrm{BBr}_{3}$, DCM, -78 ${ }^{\circ} \mathrm{C}-\mathrm{rt}, 1.5$ h (50-95\%); (c) 1.3 equiv $\mathrm{ClR}^{2}, \mathrm{CsCO}_{3}, \mathrm{KI}, \mathrm{DMF}, \mathrm{mw}, 160{ }^{\circ} \mathrm{C}, 20 \mathrm{~min}(72-93 \%)$. All analogs purified to $>98 \%$ by mass-directed preparative HPLC. ${ }^{12}$ 

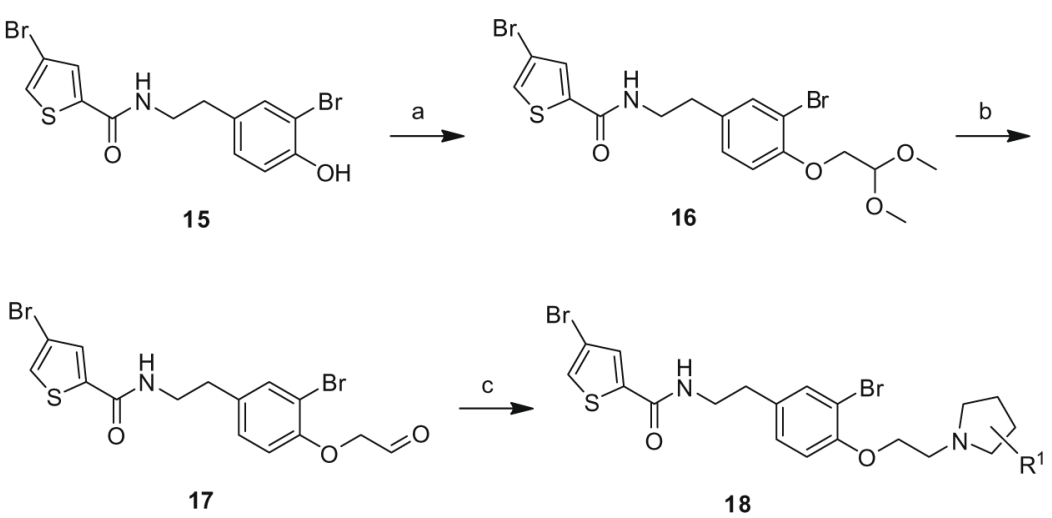

Scheme 2.

Second generation library synthesis. Reagents and conditions: (a) $\mathrm{BrCH}_{2} \mathrm{CH}(\mathrm{OMe})_{2}$, $\mathrm{Cs}_{2} \mathrm{CO}_{3}{ }^{2-}$, KI, DMF, reflux (70\%); (b) TosOH, mw, $160{ }^{\circ} \mathrm{C}, 10 \mathrm{~min}(60 \%)$; (c) functionalized pyrrolidine, MP-(OAc) $)_{3} \mathrm{H}, \mathrm{DCM}$, rt (40-85\%). All analogs purified to $>98 \%$ by mass-directed preparative HPLC. ${ }^{12}$ 
<smiles>COc1ccc(CCN2C(=O)c3ccccc3C2=O)cc1Br</smiles>

11

21<smiles></smiles>

22

23

d,e<smiles>[R]C(=O)NCCc1ccc(OCCN2CCCC2)c(Br)c1</smiles>

24

Scheme 3.

Third generation library synthesis. Reagents and conditions: (a) 1,2-dicarboxybenzene, DIC, HOBt, DIEA, DCM, rt, 12 h (99\%); (b) $\mathrm{BBr}_{3}$, DCM, $-78{ }^{\circ} \mathrm{C}-\mathrm{rt}, 1.5 \mathrm{~h}(95 \%)$; (c) 1.3 equiv Chloroethyl pyrrolidine, $\mathrm{CsCO}_{3}, \mathrm{KI}, \mathrm{DMF}, \mathrm{mw}, 160{ }^{\circ} \mathrm{C}, 20 \min \left(93 \%\right.$ ); (d) (i) $\mathrm{N}_{2} \mathrm{H}_{4}$, mw, $160{ }^{\circ} \mathrm{C}$; (ii) SCX; (e) $\mathrm{R}^{1} \mathrm{COOH}$, DIC, HOBt, DIEA, DCM, rt, $12 \mathrm{~h}$ (64-98\%). All analogs purified to $>98 \%$ by mass-directed preparative HPLC. ${ }^{12}$ 
Table 1

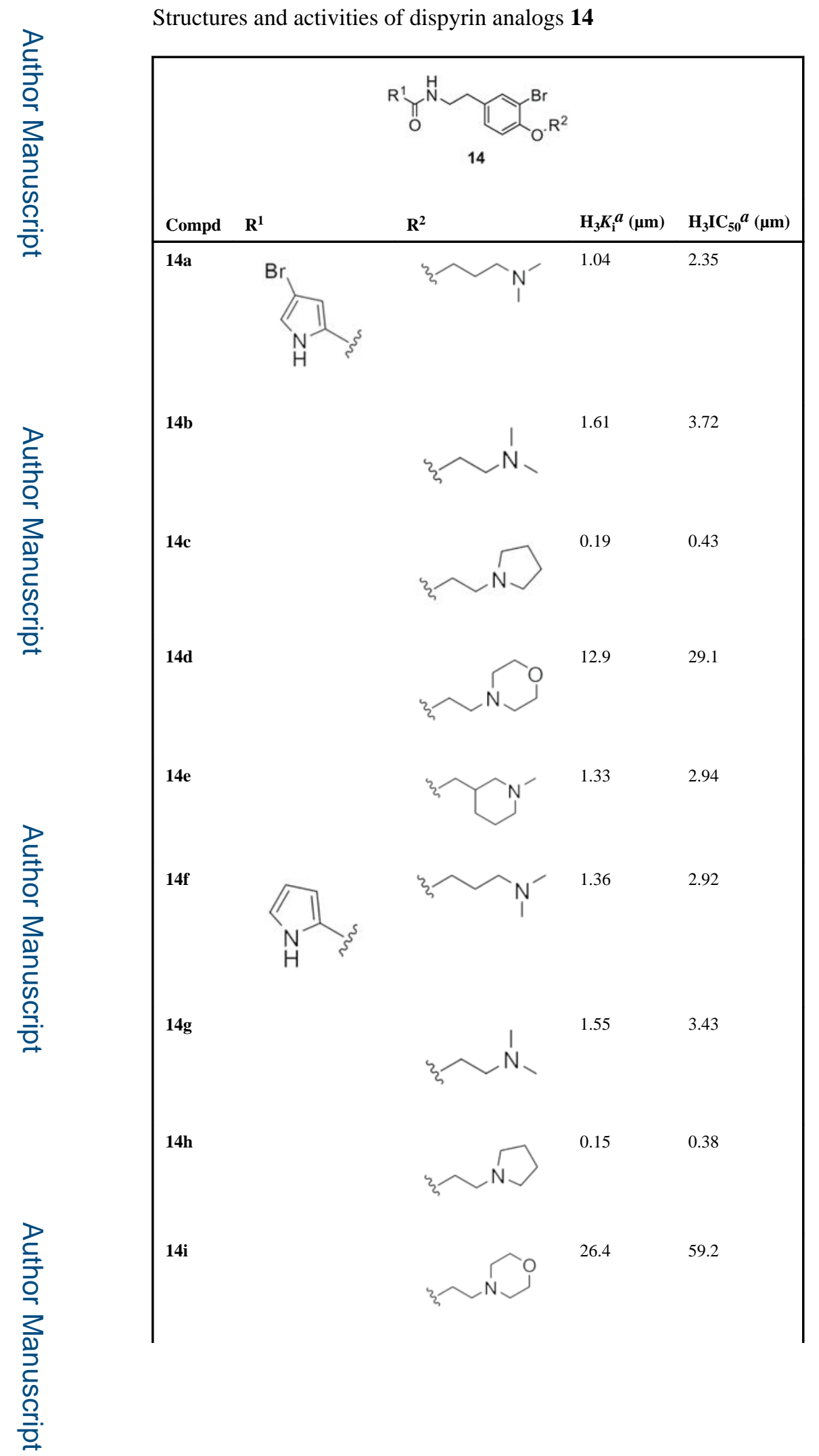

Bioorg Med Chem Lett. Author manuscript; available in PMC 2016 March 16. 


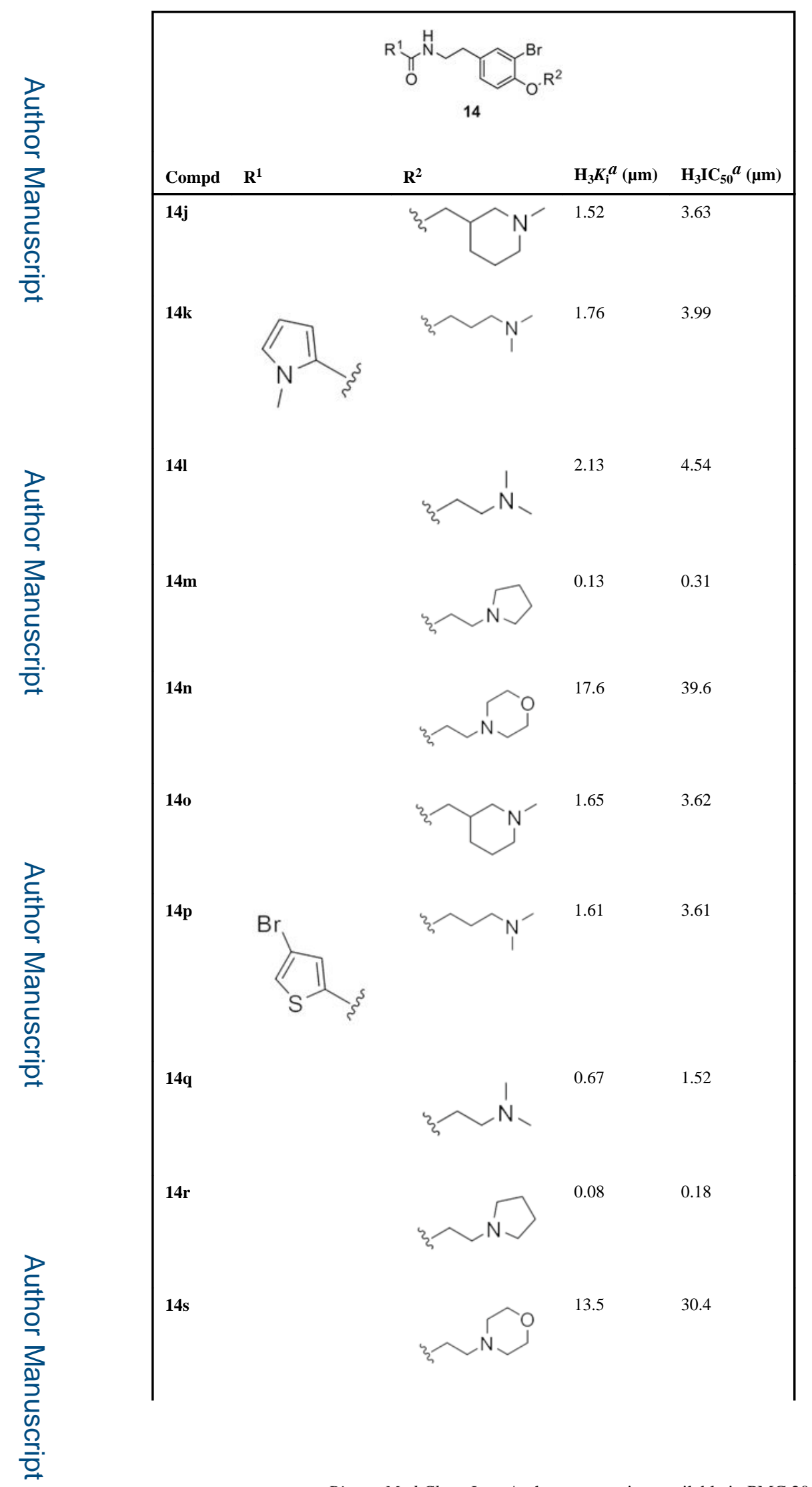

Bioorg Med Chem Lett. Author manuscript; available in PMC 2016 March 16. 


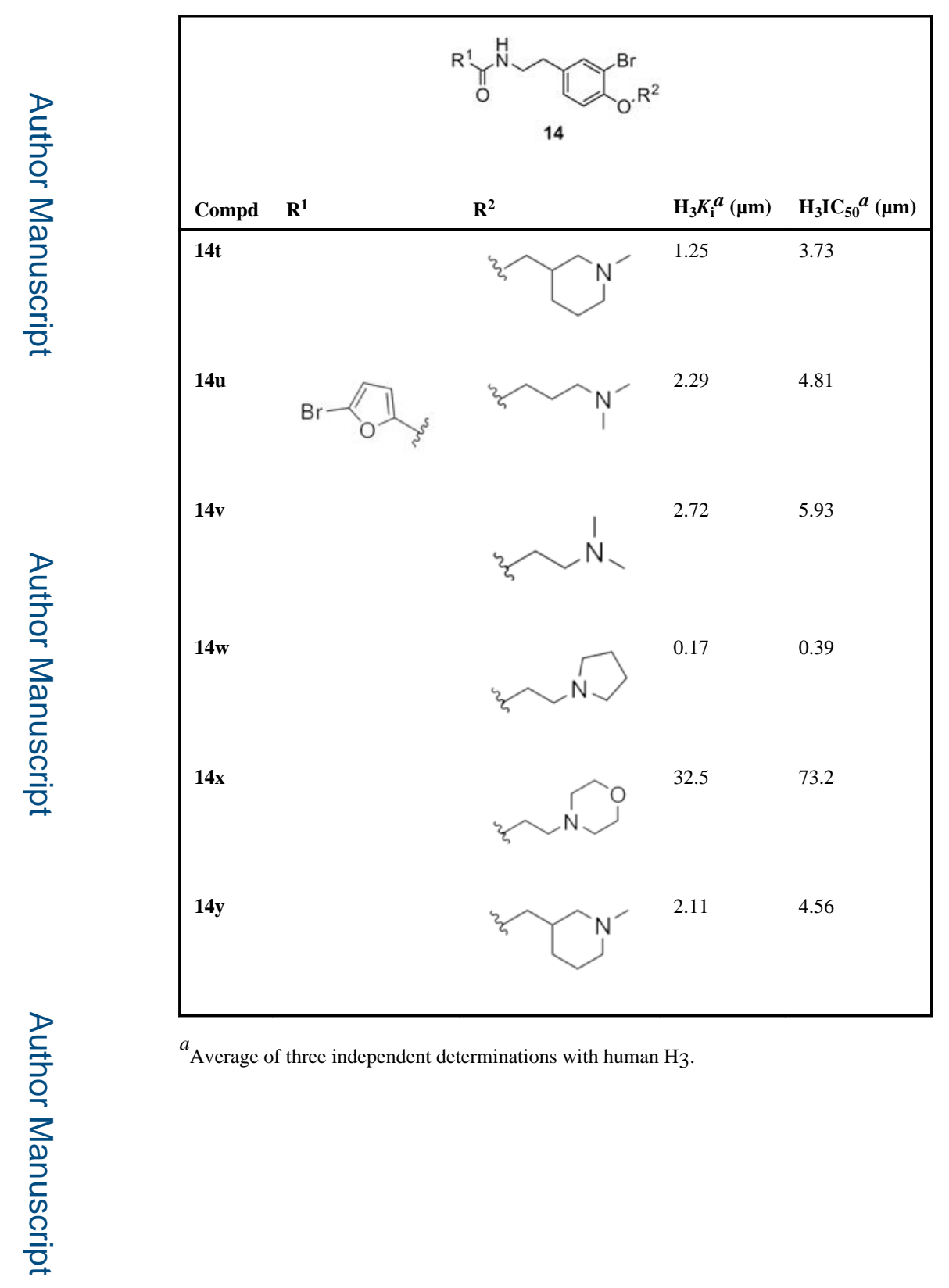

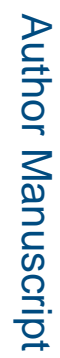

Bioorg Med Chem Lett. Author manuscript; available in PMC 2016 March 16. 


\section{Table 2}

Structures and activities of dispyrin analogs 18

\begin{tabular}{|llll|}
\hline $\mathbf{C o m p d}$ & $\mathbf{R}^{\mathbf{1}}$ & $\mathbf{H}_{\mathbf{3}} \boldsymbol{K}_{\mathbf{i}}^{\boldsymbol{a}}(\boldsymbol{\mu m})$ & $\mathbf{H}_{\mathbf{3}} \mathbf{I C}_{\mathbf{5 0}} \boldsymbol{a}^{(\boldsymbol{\mu m})}$ \\
\hline $\mathbf{1 8 a}$ & $(S)-2-\mathrm{Me}$ & 0.31 & 0.71 \\
$\mathbf{1 8 b}$ & $(S)-2-\mathrm{Me}$ & 0.33 & 0.75 \\
$\mathbf{1 8 c}$ & $(S)-3-\mathrm{F}$ & 1.10 & 2.11 \\
$\mathbf{1 8 d}$ & $(S)-3-\mathrm{F}$ & 1.15 & 2.52 \\
\hline
\end{tabular}

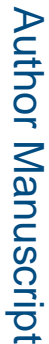

${ }^{a}$ Average of three independent determinations. 
Table 3

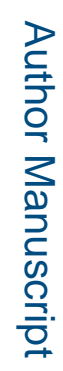

Structures and activities of dispyrin analogs 24

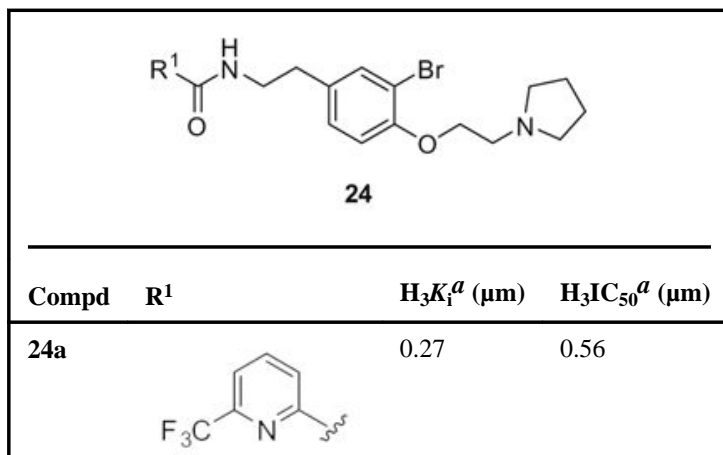

24b<smiles>Sc1cnco1</smiles>

0.03

0.08

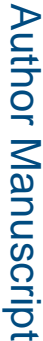

$24 c$

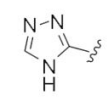

0.43

0.97

24d<smiles>Sc1nccs1</smiles>

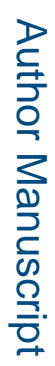

$24 \mathrm{e}$<smiles>Sc1cncs1</smiles>

0.12

0.26

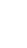

$24 f$<smiles>Cc1cccc(Cl)c1</smiles>

0.25

0.55<smiles>COc1cccc(Br)c1</smiles>

0.21

0.45

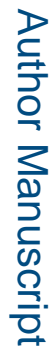

$24 h$

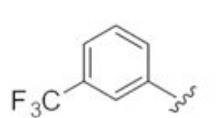

0.44

0.98 